\title{
Modelling of carbon isotope discrimination by vegetation
}

\author{
D. Hidy ${ }^{1}$ \\ L. Haszpra ${ }^{2}$ \\ Z. Barcza $^{3}$ \\ A. Vermeulen ${ }^{4}$ \\ Z. Tuba $^{5}$ \\ Z. Nagy ${ }^{1}$ \\ ${ }^{1}$ Institute of Botany and Ecophysiology, Szent István University \\ ${ }^{2}$ Hungarian Meteorological Service \\ ${ }^{3}$ Department of Meteorology, Eötvös Loránd University \\ ${ }^{4}$ Department of Air Quality \& Climate Change, Energy Research Center of the Netherlands \\ ${ }^{5}$ Plant Ecological Research Group at Botanical and Ecophysiological Institute
}

Published in PHOTOSYNTHETICA 47 (3): 457-470, 2009 


\title{
Modelling of carbon isotope discrimination by vegetation
}

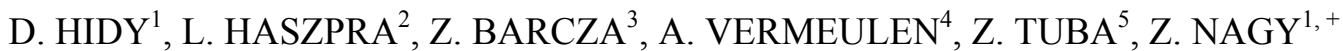 \\ Institute of Botany and Ecophysiology, Szent István University, Páter Károly u. 1., H-2100 Gödöllö, Hungary ${ }^{1}$ \\ Hungarian Meteorological Service, Gilice tér 39., H-1181 Budapest, Hungary ${ }^{2}$ \\ Department of Meteorology, Eötvös Loránd University, Pázmány Péter sétány 1/A, H-1119 Budapest, Hungary ${ }^{3}$ \\ Department of. Air Quality \& Climate Change, Energy Research Center of the Netherlands, P.O. Box 1, \\ NL-1755 ZG Petten, The Netherlands ${ }^{4}$ \\ Plant Ecological Research Group at Botanical and Ecophysiological Institute, H2103 Gödöllö Páter 1., Hungary
}

\begin{abstract}
The paper presents a simple box model simulating the temporal variation of atmospheric ${ }^{13} \mathrm{CO}_{2}$ concentration, atmospheric $\mathrm{CO}_{2}$ mixing ratio and ${ }^{13} \mathrm{C}$ content of plant material. The model is driven by observed meteorological and measured biosphere-atmosphere $\mathrm{CO}_{2}$ exchange data. The model was calibrated and validated using measurements from a Hungarian atmospheric monitoring station. The simulated atmospheric stable carbon isotope ratio data agreed well with the measured ratios considering both the magnitude and the seasonal dynamics. Observed deviations between the measured and simulated $\delta^{13} \mathrm{C}_{\text {air }}$ values were systematically negative in winters, while deviations were random in sign and smaller by an order of magnitude during periods when the vegetation was photosynthetically active. This difference, supported by a significant correlation between the deviation and modeled fossil fuel contributions to $\mathrm{CO}_{2}$ concentration, suggests the increased contribution of ${ }^{13} \mathrm{C}$-depleted fossil fuel $\mathrm{CO}_{2}$ from heating and the lower boundary layer heights during winter.
\end{abstract}

Additional key words: atmospheric modelling, ${ }^{13} \mathrm{C}$, carbon flux data, carbon isotope discrimination, carbon stable isotopes, discrimination.

\section{Introduction}

Carbon (C) is the essential building stone of life on Earth having two naturally occurring stable isotopes $\left({ }^{12} \mathrm{C}\right.$ and ${ }^{13} \mathrm{C}$ ) and one radioactive isotope $\left({ }^{14} \mathrm{C}\right)$. The share of ${ }^{12} \mathrm{C}$, ${ }^{13} \mathrm{C}$ and ${ }^{14} \mathrm{C}$ are $0.9893,0.0107$, and $\sim 10^{-12}$, respectively (Jones 1992). The stable carbon isotope content of carbon dioxide $\left(\mathrm{CO}_{2}\right)$ in air contains unique information on the biological and physical processes that govern the $\mathrm{CO}_{2}$ budget of the atmosphere (Farquhar et al. 1989). Though ${ }^{13} \mathrm{CO}_{2}$ measurements in air are rather expensive and therefore rare, they could help to understand the functioning of the vegetation and give information on the contribution of the anthropogenic sources to the atmospheric carbon budget. Consequently, it would be useful to simulate ${ }^{13} \mathrm{CO}_{2}$ in air with a mathematical model. Biophysical models have the capacity of simulating isotope discrimination caused by the changes of the environmental parameters. Few biogeochemical models have been developed to simulate isotope discrimination between the atmosphere and the vegetation (Lai et al. 2004; Suits et al. 2005; Chen et al. 2006).

Received 27 February 2009, accepted 3 June 2009.

${ }^{+}$Corresponding author; e-mail: nagy.zoltan@mkk.szie.hu

Abbreviations: c - mixing ratio; E - transpiration rate; FT - airmixing function; $g$ - gaseous conductance; GPP - gross primary production; L - likelihood; LE - latent heat flux; $\mathrm{M}_{\mathrm{C}}$ - average molar mass of carbon; NEE - net ecosystem exchange; NPP - net primary production; $\mathrm{p}$ - pressure; $\mathrm{PBL}$ - planetary boundary layer height; $\mathrm{R}$ - gas constant; rad - global radiation; RMSE - root mean square error; T - temperature; TNBL - top of the nocturnal boundary layer; TR - total ecosystem respiration; TRL - top of the residual layer; VPD - vapor pressure deficit; $\gamma$ - adiabatic temperature lapse rate; $\delta{ }^{13} \mathrm{C}-{ }^{13} \mathrm{C}$ isotopic abundance; $\Delta-$ discrimination against ${ }^{13} \mathrm{CO}_{2}$.

Acknowledgements: The authors thank James White, Bruce Vaughn (INSTAAR) and Pieter Tans (NOAA ESRL) for $\delta^{13} \mathrm{C}_{\text {air }}$ data. Carbon dioxide mixing ratio and meteorological measurements at Hegyhátsál were supported by the Hungarian Scientific Research Fund (OTKA T042941, K75638 and OTKA CK77550), as well as by the 5th and 6th R+D Framework Programme of the European Commission (AEROCARB - EVK2-CT-1999-00013, CarboEurope-IP - GOCE-CT-2003-505572). The authors also highly appreciate the help of Frédéric Chevallier (Laboratoire des Sciences du Climat et de l'Environnement/IPSL, CEA-CNRS-UVSQ, Gif-sur-Yvette, France). 
Measurement and modelling of stable carbon isotope have produced reasonable results for the understanding of the global carbon budget, because ${ }^{13} \mathrm{CO}_{2}$-in-air is a powerful tracer for partitioning terrestrial and oceanic sinks of atmospheric $\mathrm{CO}_{2}$ (terrestrial plants discriminate about 10 times more against the heavier isotope than ocean) (Chen et al. 2006).

We developed a simple box model (13C FLUX model) to simulate seasonal and diurnal variations of stable carbon isotope content of carbon-dioxide $\left(\mathrm{CO}_{2}\right)$ in air. Our simple mathematical model predicts the stable carbon isotope ratio from measured vertical carbon dioxide and latent heat fluxes and ancillary meteorological data, all of which might be available continuously

\section{Materials and methods}

Theoretical background: Since plants preferentially use ${ }^{12} \mathrm{CO}_{2}$ in photosynthesis (diffusion and carboxylation processes discriminate against the heavier isotope), $\mathrm{CO}_{2}$ in the atmosphere becomes relatively enriched in ${ }^{13} \mathrm{CO}_{2}$ during daytime (Chen et al. 2006). While discrimination is linked to photosynthesis and therefore is restricted to daytime, ecosystem respiration components continuously contribute to the $\mathrm{CO}_{2}$ content of the atmosphere. It is commonly assumed that there is no fractionation during respiration (Jones 1992), so carbon dioxide respired has the same stable isotope composition as the live plant tissue. During the growing season photosynthetic discrimination dominates during daytime, while respiration dominates at night, resulting in a diurnal variation in the atmospheric stable carbon isotope composition. In practice, the ${ }^{13} \mathrm{C}$ isotopic abundance is usually expressed as deviation from PDB (Pee Dee Belemnite $)$ standard $\left[\left({ }^{13} \mathrm{C} /{ }^{12} \mathrm{C}_{\text {stnd }}=0.01124\right)\right.$ - abundance ratio in a fossil belemnite formation], to which we refer as $\delta^{13} \mathrm{C}$ (Jones 1992):

$$
\delta^{13} \mathrm{C}_{\text {sample }}(\%)=\frac{\left({ }^{13} \mathrm{C} /{ }^{12} \mathrm{C}\right)_{\text {sample }}}{\left({ }^{13} \mathrm{C} /{ }^{12} \mathrm{C}\right)_{\text {stnd }}}-1
$$

The discrimination is usually defined by:

$$
\Delta=\frac{\delta^{13} \mathrm{C}_{\text {air }}-\delta^{13} \mathrm{C}_{\text {plant }}}{1+\delta^{13} \mathrm{C}_{\text {plant }}}
$$

where $\delta^{13} \mathrm{C}_{\text {air }}$ is the ${ }^{13} \mathrm{C}$ isotopic abundance of the air and $\delta^{13} \mathrm{C}_{\text {plant }}$ is the ${ }^{13} \mathrm{C}$ isotopic abundance of the plant material.

For $\mathrm{C}_{3}$ plants, respired $\mathrm{CO}_{2}$ is significantly depleted in ${ }^{13} \mathrm{C}$, with $\delta^{13} \mathrm{C}_{\text {plant }}$ on the order of $-25 \%$ o to $-38 \%$ (Jones 1992; Bowling et al. 2008). Because respired $\mathrm{CO}_{2}$ and $\mathrm{CO}_{2}$ left behind in the atmosphere during photosynthesis have different isotope ratios, the isotopic composition of $\mathrm{CO}_{2}$ entering and leaving the ecosystems can provide information on the balance of photosynthesis and respiration, so that we can estimate the contribution of the processes (Hemming et al. 2005). at monitoring sites (e.g. in the FLUXNET network; Baldocchi et al. 2001). The advantages of a simple model structure are that the model requires less input data and computing time compared to complex models.

Biogeochemical models generally use prescribed (annually fixed) atmospheric carbon dioxide mixing ratio data for the calculation of plant photosynthetic carbon uptake. As the present model also simulates ambient $\mathrm{CO}_{2}$ mixing ratio, the latter can be used for the estimation of photosynthesis in plant material at higher precision (Farquhar et al. 1980; Harnos et al. 2002).

Our model is calibrated and validated using data from a Hungarian monitoring site, Hegyhátsál.

Measurement site: The site specific measurements used as input and verification data are provided at a Hungarian tall tower monitoring site located at Hegyhátsál, in western Hungary (46 $57^{\circ} \mathrm{N}, 1^{\circ} 39^{\prime} \mathrm{E}, 248 \mathrm{~m}$ a.s.1.) (Haszpra et al. 2001). Vertical fluxes of carbon dioxide and water vapor, representative for an extended region covered by different agricultural fields and forest patches, are measured by the eddy covariance technique at $82 \mathrm{~m}$ elevation above the ground (Haszpra et al. 2005). Continuous measurements of $\mathrm{CO}_{2}$ mixing ratio, air temperature, relative humidity and wind profiles (10-115 $\mathrm{m}$ above ground) began in September 1994, while $\mathrm{CO}_{2}$ and water vapor flux measurements started in April 1997. The monitoring station is a rural site with little anthropogenic activity in the vicinity that could influence the measurements significantly. Information on the height of the planetary boundary layer (PBL) above the station was retrieved from the MARS database of the European Centre for Medium-Range Weather Forecasts $(E C M W F)$ on a $0.25 \times 0.25$ degree regular grid. In the calculations the data from the grid point closest to the monitoring site are used (distance from the closest grid point is $8.9 \mathrm{~km}$ ). In the database the boundary layer height data are available on a grid with 3-hour temporal resolution.

The tower is also a sampling site for NOAA ESRL global cooperative air sampling network (code: HUN http://www.esrl.noaa.gov/gmd/ccgg/flask.html). Air is sampled once a week at $96 \mathrm{~m}$ height in the early afternoon hours using glass flasks. The air samples are analyzed by NOAA ESRL Global Monitoring Division for $\mathrm{CO}_{2}$ and other greenhouse gases, as well as by the Institute for Arctic and Alpine Research (INSTAAR), University of Colorado, among others, for stable isotopes of $\mathrm{C}$ in $\mathrm{CO}_{2}$.

The model: The model domain is an air-column with the height of PBL, forming a box on the surface (box-model). The base of the box has an area of $1 \mathrm{~m}^{2}$.It is assumed that the air inside the box is well mixed, meaning that the atmospheric mixing ratio of $\mathrm{CO}_{2}$ and its carbon isotope 
composition is uniform in space. An adiabatic temperature lapse rate $(\gamma=-0.98 \mathrm{~K} / 100 \mathrm{~m}$ during daytime and $\gamma=-0.3 \mathrm{~K} / 100 \mathrm{~m}$ during nighttime) and barometric vertical pressure gradient are assumed inside the box, which are used to calculate the average temperature and air pressure for the box.

The height of the box varies in time; it is equal to the height of the boundary layer from the ECMWF data at any moment. Such a box model cannot handle the advection processes, which is an obvious limitation of this simple model type.

The simulation time step was one hour. As initial condition the ${ }^{13} \mathrm{CO}_{2}$ content of the box was calculated from the $\mathrm{CO}_{2}$ mixing ratio and atmospheric stable carbon isotope ratio $\left(\delta^{13} \mathrm{C}_{\text {air }}\right)$ measured (NOAA ESRL data). As a first approach we assume that the plant and soil carbon pools can be divided into two parts: short-term (carbon residence time is up to a week) and long-term (carbon residence time is longer than a week) pools (Bowling et al. 2008).

In every simulation step the atmospheric mixing ratio of $\mathrm{CO}_{2}$ and its stable isotope ratio in the box were recalculated by taking into account the mixing with the upper atmospheric layers (when the box is expanding upward) as well as the source and sink processes at the surface. Using eddy covariance flux data and the simulated atmospheric mixing composition of $\mathrm{CO}_{2}$, stable carbon isotope ratio of plant material was also recalculated. The model requires continuous input data, therefore gapfilled carbon-dioxide and meteorological data were used (Haszpra et al. 2005).

Changes in $\delta^{13} \mathrm{C}_{\text {air }}$ in the model were driven by the change of the boundary layer height and by the ecosystem carbon exchange processes. The input variables of the model are presented in Table 1.

Table 1. The input variables of the isotope model

\begin{tabular}{llll}
\hline Name & Abbreviation & Time step & Unit \\
\hline total ecosystem respiration & $\mathrm{TR}$ & hourly & $\mathrm{mg} \mathrm{C} \mathrm{m}^{-2} \mathrm{~s}^{-1}$ \\
net ecosystem exchange & $\mathrm{NEE}$ & hourly & $\mathrm{mg} \mathrm{C} \mathrm{m}^{-2} \mathrm{~s}^{-1}$ \\
latent heat flux & $\mathrm{LE}$ & hourly & $\mathrm{mg} \mathrm{H}_{2} \mathrm{O} \mathrm{m}^{-2} \mathrm{~s}^{-1}$ \\
planetary boundary layer height & $\mathrm{PBL}$ & 3-hourly & $\mathrm{m}$ \\
air temperature & $\mathrm{T}$ & hourly & $\mathrm{K}$ \\
vapor pressure deficit & $\mathrm{VPD}$ & hourly & $\mathrm{Pa}$ \\
air pressure & $\mathrm{p}$ & daily & $\mathrm{Pa}$ \\
global radiation & $\mathrm{rad}$ & hourly & $\mathrm{W} \mathrm{m}^{-2}$ \\
\hline
\end{tabular}

\section{Calculation of the changes in boundary layer height}

The Planetary Boundary Layer (PBL) is the part of the troposphere influenced directly by the surface processes (Stull 1988). Above the PBL, in the free troposphere, the effect of the surface forcings is decreased. During daytime the PBL consists of the mixed layer, which is well mixed due to thermally and mechanically driven turbulence. There is a layer between the mixed layer and the free troposphere called entrainment zone where there is entrainment of free tropospheric air downward and mixing of boundary layer air upward via overshooting thermals. After sunset the thermals cease, and the mixed layer decomposes into two layers: the nocturnal stable boundary layer at the surface and the residual layer above it (Stull 1988). The residual layer has no contact with the surface where the sources and sinks of $\mathrm{CO}_{2}$ are located, therefore it preserves the $\mathrm{CO}_{2}$ concentration and stable isotope composition of the late mixing layer.

In our box model the height of the box (h) is changing with that of the boundary layer. If $h$ in the current simulation step is less than in the previous one, part of the air column is excluded from further computations, and concentrations within the remaining box are assumed to be unchanged. If $h$ in the current simulation step is higher than in the previous one, air is entering the box from the atmospheric layers above, and the concentrations in the box are changing due to the mixing.

During the daytime expansion of the boundary layer, air from the residual layer (remaining from the previous night) will be mixed into the model domain (represented by the box). However, there is also a continuous limited mixing between the residual layer and the free troposphere, which has to be taken into account in the simulation. In fact, when the boundary layer expands, a mixture of residual layer air and free tropospheric air enters the box. We assume that close to the surface the proportion of free tropospheric air is small, but this increases with height (Stull 1988).

Since there were no measurements available on the dependence of the free tropospheric characteristics with height, we simulated the mixing of free tropospheric air downward into the residual layer and the balancing flow upward. Function FT(h) was defined giving the proportion of free tropospheric air as the function of height. For the compilation of the function we introduced the following parameters:

TNBL (top of the nocturnal boundary layer) is the minimum height of the nocturnal boundary layer. It is determined for each simulation day and valid from the previous end of the daily radiation period to the next one. 
End of the daily radiation period is defined as the time when the value of the global solar radiation falls below $2 \mathrm{Wm}^{-2}$.

TRL (top of the residual layer) is equal to the height of the planetary boundary layer one hour before the end of the daily radiation period. It is determined for each simulation day and valid from the end of the daily radiation period to the next one.

We assume that the elevation, where some air with free tropospheric characteristics appears, is between TNBL and TRL, and depends on the depth of the residual layer. The elevation, above which the incorporated air has only free tropospheric characteristics, is above TRL and it also depends on the depth of the residual layer:

$\mathrm{h}_{\mathrm{FT} 0}$ : defined as the elevation below which no mixing of free tropospheric air occurs (TNBL $<\mathrm{h}_{\mathrm{FT} 0}<\mathrm{TRL}$ )

$\mathrm{h}_{\mathrm{FT} 100}$ : defined as the elevation above which $100 \%$ of the air has free tropospheric origin $\left(\mathrm{h}_{\mathrm{FT} 100}>\mathrm{TRL}\right)$.

In the lack of theoretically soundly based functions we estimated FT(h) arbitrarily in the form of an exponential function:

$$
\mathrm{FT}(\mathrm{h})=\frac{\exp \left[\mathrm{k}\left(\frac{\mathrm{h}-\mathrm{h}_{\mathrm{FT} 0}}{\mathrm{~h}_{\mathrm{FT} 100}-\mathrm{h}_{\mathrm{FT} 0}}\right)\right]-1}{\exp (\mathrm{k})-1} ; \mathrm{h}_{\mathrm{FT} 0} \leq \mathrm{h} \leq \mathrm{h}_{\mathrm{FT} 100}
$$

$$
\text { and } \mathrm{FT}(\mathrm{h})=0 ; \mathrm{h}<\mathrm{h}_{\mathrm{FT} 0} \text { or } \mathrm{FT}(\mathrm{h})=1 ; \mathrm{h}>\mathrm{h}_{\mathrm{FT} 100}
$$

where $\mathrm{k}$ is the power of the exponential function determining its shape.

We assume that the shape of FT(h) function changes with time (because of the different air-mixing processes during a year). As a first approach we define $\mathrm{k}_{\text {summer }}$ (from April to September) and $\mathrm{k}_{\text {winter }}$ (from October to March).

Air from the residual layer is characterized by the simulated data of the last simulation hour before sunset. Following the method of Chen et al. (2006) in terms of $\mathrm{CO}_{2}$ mixing ratio and ${ }^{13} \mathrm{C}$-in- $\mathrm{CO}_{2}$ abundance in the air of the free troposphere were taken equal to those in the marine boundary layer from GLOBALVIEW data products (GLOBALVIEW-CO2, 2007; GLOBALVIEWCO2C13, 2007).

\section{Calculation of the changes caused by plant processes}

After calculating $\mathrm{h}$ we can determine the total masses of ${ }^{12} \mathrm{C}\left(\mathrm{m}_{12 \mathrm{C}}\right)$ and ${ }^{13} \mathrm{C}$ isotopes $\left(\mathrm{m}_{13 \mathrm{C}}\right)$ being in the boundary layer represented by our box. Using the ideal gas law:

$$
\begin{aligned}
& \mathrm{m}_{{ }^{12} \mathrm{C}}=\frac{\mathrm{p}}{\mathrm{RT}} \mathrm{M}_{\mathrm{C}} \mathrm{c}_{\mathrm{CO}_{2}} \mathrm{~h}\left(1-\frac{{ }^{13} \mathrm{C}}{{ }^{12} \mathrm{C}+{ }^{13} \mathrm{C}}\right), \\
& \mathrm{m}_{{ }^{13} \mathrm{C}}=\frac{\mathrm{p}}{\mathrm{RT}} \mathrm{M}_{\mathrm{C}} \mathrm{c}_{\mathrm{CO}_{2}} \mathrm{~h} \frac{{ }^{13} \mathrm{C}}{{ }^{12} \mathrm{C}+{ }^{13} \mathrm{C}}
\end{aligned}
$$

where $\mathrm{T}$ is the average air temperature in the box calculated from the surface temperature and the temperature lapse rate, $\mathrm{p}$ is the average atmospheric pressure calculated from the surface pressure and taking into account the barometric pressure gradient, $\mathrm{R}$ is the gas constant, $\mathrm{M}_{\mathrm{C}}$ is the average molar mass of carbon (12.01 $\left.\mathrm{g} \mathrm{mol}^{-1}\right), \mathrm{c}_{\mathrm{CO}_{2}}$ is the atmospheric $\mathrm{CO}_{2}$ mixing ratio, while $\mathrm{h}$ is the height of the boundary layer equal to that of the box. ${ }^{13} \mathrm{C} /\left({ }^{12} \mathrm{C}+{ }^{13} \mathrm{C}\right)$ can be calculated from $\delta^{13} \mathrm{C}_{\text {air }}$.

The mass of $\mathrm{CO}_{2}$ and its ${ }^{13} \mathrm{C}$ content in the box are also influenced by the exchange processes at the surface. The gross primary production (GPP; is the total amount of carbon that is fixed by the plant in photosynthesis) is calculated using the following equation:

$$
\mathrm{GPP}=\mathrm{TR}-\mathrm{NEE}
$$

where NEE is the measured net ecosystem exchange of $\mathrm{CO}_{2}$ (positive if $\mathrm{CO}_{2}$ is released into the atmosphere by the ecosystem) and TR is the total ecosystem respiration (carbon released by respiration).

The ${ }^{13} \mathrm{C}$ isotopic abundance of the assimilated carbon equals to that of the plant material $\left(\delta^{13} \mathrm{C}_{\mathrm{assim}}\right)$ :

$$
\delta^{13} \mathrm{C}_{\text {assim }}=\delta^{13} \mathrm{C}_{\text {plant }}
$$

In order to model the isotopic composition of ecosystem released $\mathrm{C}\left(\delta^{13} \mathrm{C}_{\text {released }}\right)$, the following assumptions were made: soil respiration is about $50 \%$ of the total respiration, half of which is root respiration (carbon released from short-term carbon pool), while the other half is microbial respiration (carbon released from longterm carbon pool) (Schulze et al. 2006). Isotope ratio of root respiration was taken equal to that of material from short-term carbon pool, while that of microbial respiration was taken equal to that of the material from long-term carbon pool in the soil. We consider that the carbon isotope ratio in short-term carbon pool was assumed to be equal to the isotope ratio of plant material $\left(\delta^{13} C_{a i r}\right)$ calculated below (Jones 1992). The carbon isotope ratio in long-term carbon pool was set to $-22 \%$ and we assume that it does not change during the simulation.

$$
\delta^{13} \mathrm{C}_{\text {released }}=0.75 \delta^{13} \mathrm{C}_{\text {plant }}+0.25 \delta^{13} \mathrm{C}_{\text {longterm }},
$$

where $\delta^{13} \mathrm{C}_{\text {longterm }}=-22 \%$

From the ${ }^{13} \mathrm{C}$ isotopic abundance ${ }^{13} \mathrm{C}$ isotope ratio can be calculated:

$$
\begin{aligned}
& \left({ }^{13} \mathrm{C} /{ }^{12} \mathrm{C}\right)_{\text {sample }}=\left(1+\delta^{13} \mathrm{C}\right)\left({ }^{13} \mathrm{C} /{ }^{12} \mathrm{C}\right)_{\text {stnd }} \\
& \left(\frac{{ }^{13} \mathrm{C}}{{ }^{12} \mathrm{C}+{ }^{13} \mathrm{C}}\right)_{\text {sample }}=\frac{\left({ }^{13} \mathrm{C} /{ }^{12} \mathrm{C}\right)_{\text {sample }}}{\left({ }^{13} \mathrm{C} /{ }^{12} \mathrm{C}\right)_{\text {sample }}+1}
\end{aligned}
$$

The ${ }^{13} \mathrm{C}$ flux $\left(\mathrm{F}\left({ }^{13} \mathrm{C}\right)\right)$ can be expressed as:

$$
\mathrm{F}\left({ }^{13} \mathrm{C}\right)=\left(\frac{{ }^{13} \mathrm{C}}{{ }^{13} \mathrm{C}+{ }^{12} \mathrm{C}}\right)_{\text {assim }} \mathrm{GPP}-\left(\frac{{ }^{13} \mathrm{C}}{{ }^{13} \mathrm{C}+{ }^{12} \mathrm{C}}\right)_{\text {released }} \mathrm{TR}
$$


where $\left(\frac{{ }^{13} \mathrm{C}}{{ }^{13} \mathrm{C}+{ }^{12} \mathrm{C}}\right)$ assim and $\left(\frac{{ }^{13} \mathrm{C}}{{ }^{13} \mathrm{C}+{ }^{12} \mathrm{C}}\right)_{\text {released }}$

are the stable carbon isotope ratio of assimilated and released carbon-dioxide, respectively.

To simulate the dynamic change in discrimination against ${ }^{13} \mathrm{CO}_{2}$ during different weather conditions and to make it dependent on photosynthetic activity of the vegetation, a physiologically based model part was built, which is described below.

$\mathrm{CO}_{2}$ partial pressure within the leaves $\left(\mathrm{p}\left(\mathrm{CO}_{2}\right)_{\text {leaf }}\right)$ was calculated using the leaf scale approach, as adapted to carbon flux measurements data by Farquhar et al. (1982). If the plant is in steady state condition with environmental conditions, the molar flux of $\mathrm{C}$ into the plant from the atmosphere (net primary production; NPP $[\mathrm{mmol}(\mathrm{C})$ $\left.\mathrm{m}^{-2} \mathrm{~s}^{-1}\right]$ ) and the rate of transpiration of water per unit area $\left(E\left[\mathrm{mmol}\left(\mathrm{H}_{2} \mathrm{O}\right) \mathrm{m}^{-2} \mathrm{~s}^{-1}\right]\right)$ can be calculated as follows:

$$
\begin{aligned}
& \mathrm{NPP}=g_{\mathrm{CO}_{2}} \cdot \frac{\mathrm{p}\left(\mathrm{CO}_{2}\right)_{\text {air }}-\mathrm{p}\left(\mathrm{CO}_{2}\right)_{\text {leaf }}}{\mathrm{p}_{\text {air }}} 10^{3} \\
& E=g_{\mathrm{W}} \cdot \frac{\mathrm{e}_{\text {air }}-\mathrm{e}_{\text {leaf }}}{\mathrm{p}_{\text {air }}} 10^{3}
\end{aligned}
$$

where $p_{\text {air }}$ is the atmospheric pressure, $\mathrm{p}\left(\mathrm{CO}_{2}\right)_{\text {air }}-$ $\mathrm{p}\left(\mathrm{CO}_{2}\right)_{\text {leaf }}$ is the difference between ambient and innerleaf partial pressures of $\mathrm{CO}_{2}[\mathrm{~Pa}], g_{\mathrm{CO}_{2}}\left[\mathrm{mmol}(\mathrm{C}) \mathrm{m}^{-2} \mathrm{~s}^{-1}\right]$ and $g_{\mathrm{w}}\left[\mathrm{mmol}\left(\mathrm{H}_{2} \mathrm{O}\right) \mathrm{m}^{-2} \mathrm{~s}^{-1}\right]$ are gaseous conductance through the boundary layer and the stoma of the leaf regarding to carbon-dioxide and water molecules, respectively. Finally, $\mathrm{e}_{\text {air }}-\mathrm{e}_{\text {leaf }}$ is the related water vapor pressure deficit (VPD [Pa], measured data are available).

Using Eq. 11 and Eq. 12:

$$
\frac{\mathrm{NPP}}{\mathrm{E}}=\frac{g_{\mathrm{CO}_{2}}}{g_{\mathrm{W}}} \frac{\mathrm{p}\left(\mathrm{CO}_{2}\right)_{\mathrm{air}}-\mathrm{p}\left(\mathrm{CO}_{2}\right)_{\text {leaf }}}{\mathrm{VPD}}
$$

where $\frac{g_{\mathrm{CO}_{2}}}{g_{\mathrm{W}}}=0.622$ (Jones, 1992; Farquhar et al. 1982).

From Eq (14) p $\left(\mathrm{CO}_{2}\right)_{\text {leaf }}$ can be calculated:

$$
\mathrm{p}\left(\mathrm{CO}_{2}\right)_{\text {leaf }}=\mathrm{p}\left(\mathrm{CO}_{2}\right)_{\text {air }}-\frac{\mathrm{NPP}}{\mathrm{E}} \mathrm{VPD} \frac{g_{\mathrm{W}}}{g_{\mathrm{CO}_{2}}}
$$

NPP can be calculated from hourly gross primary production (GPP, $\left[\mathrm{mg}(\mathrm{C}) \mathrm{m}^{-2} \mathrm{~s}^{-1}\right]$ ) and hourly total ecosystem respiration (TR, $\left[\mathrm{mg}(\mathrm{C}) \mathrm{m}^{-2} \mathrm{~s}^{-1}\right]$ ). Since we assume that the plant respiration is $50 \%$ of the total respiration, NPP can be calculated:

$$
\mathrm{NPP}=\frac{\mathrm{GPP}-0.5 \mathrm{TR}}{\mathrm{M}_{\mathrm{C}}} ;(\text { if GPP }<0.5 \mathrm{TR} \text { then } \mathrm{NPP}=0)
$$

where $\mathrm{M}_{\mathrm{C}}$ is the average molar mass of carbon $\left[\mathrm{g} \mathrm{mol}^{-1}\right.$ ].

$E$ can be determined from measured latent heat flux
(LE, $\left[\mathrm{mg}\left(\mathrm{H}_{2} \mathrm{O}\right) \mathrm{m}^{-2} \mathrm{~s}^{-1}\right]$ ignoring soil evaporation.

$$
E=\frac{\mathrm{LE}}{\mathrm{M}_{\mathrm{H}_{2} \mathrm{O}}}
$$

where $\mathrm{M}_{\mathrm{H}_{2} \mathrm{O}}$ is the average molar mass of water $\left[\mathrm{g} \mathrm{mol}^{-1}\right.$ ].

Following the method of Farquhar (1980), Farquhar (1982) and Hemming et al. (2005) carbon isotope discrimination $(\Delta)$ can be calculated using $\mathrm{CO}_{2}$ partial pressure of the ambient air and that in the leaf:

$$
\Delta=\mathrm{a}+(\mathrm{b}-\mathrm{a}) \frac{\mathrm{p}\left(\mathrm{CO}_{2}\right)_{\text {leaf }}}{\mathrm{p}\left(\mathrm{CO}_{2}\right)_{\text {air }}}
$$

where a stands for the discrimination against the heavier isotope during diffusion of $\mathrm{CO}_{2}$ into the stomatal pore, while $b$ stands for the discrimination by Rubisco in $\mathrm{C}_{3}$ type photosynthesis.

From Eq. $2 \delta^{13} \mathrm{C}_{\text {plant }}$ can be calculated (Jones 1992):

$$
\delta^{13} \mathrm{C}_{\text {plant }}=\frac{\delta^{13} \mathrm{C}_{\mathrm{air}}-\Delta}{1+\Delta}
$$

\section{Calibration of the model}

The values of $\mathrm{k}$ (the power of the exponential function in Eq. 3), $\mathrm{h}_{\mathrm{FT} 0}$ and $\mathrm{h}_{\mathrm{FT} 100}$ are a priori unknown. $\mathrm{h}_{\mathrm{FT} 0}$ and $\mathrm{h}_{\mathrm{FT} 100}$ depend on the depth of the residual layer. To calculate these elevations two proportional numbers are defined:

FT0 is a proportional number which is used to calculate $\mathrm{h}_{\mathrm{FT} 0}$ :

$$
\mathrm{h}_{\mathrm{FT} 0}=\mathrm{TNBL}+\mathrm{FT} 0(\mathrm{TRL}-\mathrm{TNBL})
$$

FT100 is a proportional number which is used to calculate $\mathrm{h}_{\mathrm{FT} 100}$ :

$$
\mathrm{h}_{\mathrm{FT} 100}=\mathrm{TNBL}+\mathrm{FT} 100(\mathrm{TRL}-\mathrm{TNBL})
$$

Since the height of the well-mixed layer depends on the radiation processes, we assume that FT0 and FT100 have different value during the year. As first approach we define $\mathrm{FT}_{\text {summer, }}$ FT100 summer $_{\text {(from April to September) }}$ and $\mathrm{FT}_{\text {winter, }}$ FT100 $0_{\text {winter }}$ (from October to March).

Thus we have six unknown model parameters: $\mathrm{k}_{\text {summer, }}$ FT0 summer, $_{\text {FT100 }}$ summer, $\mathrm{k}_{\text {winter }}, \mathrm{FT}_{\text {winter }}, \mathrm{FT} 100_{\text {winter }}$.

Our knowledge of the world is incomplete, which means that there are several parameters to which no local measurements are available and the real world implies uncertainty about model structure and parameterization (Van Oijen et al. 2005). Beyond other methods (e.g. genetic algorithms) Bayesian statistics aims to provide such "rules and procedures for disciplined uncertainty accounting" (Van Oijen et al. 2005). As the model has a complex structure, for the determination of such unknown parameters (i.e. for the calibration of the model), the Global Optimization method offers a solution (Mosegaard and Tarantola, 1995). It is based on a large 


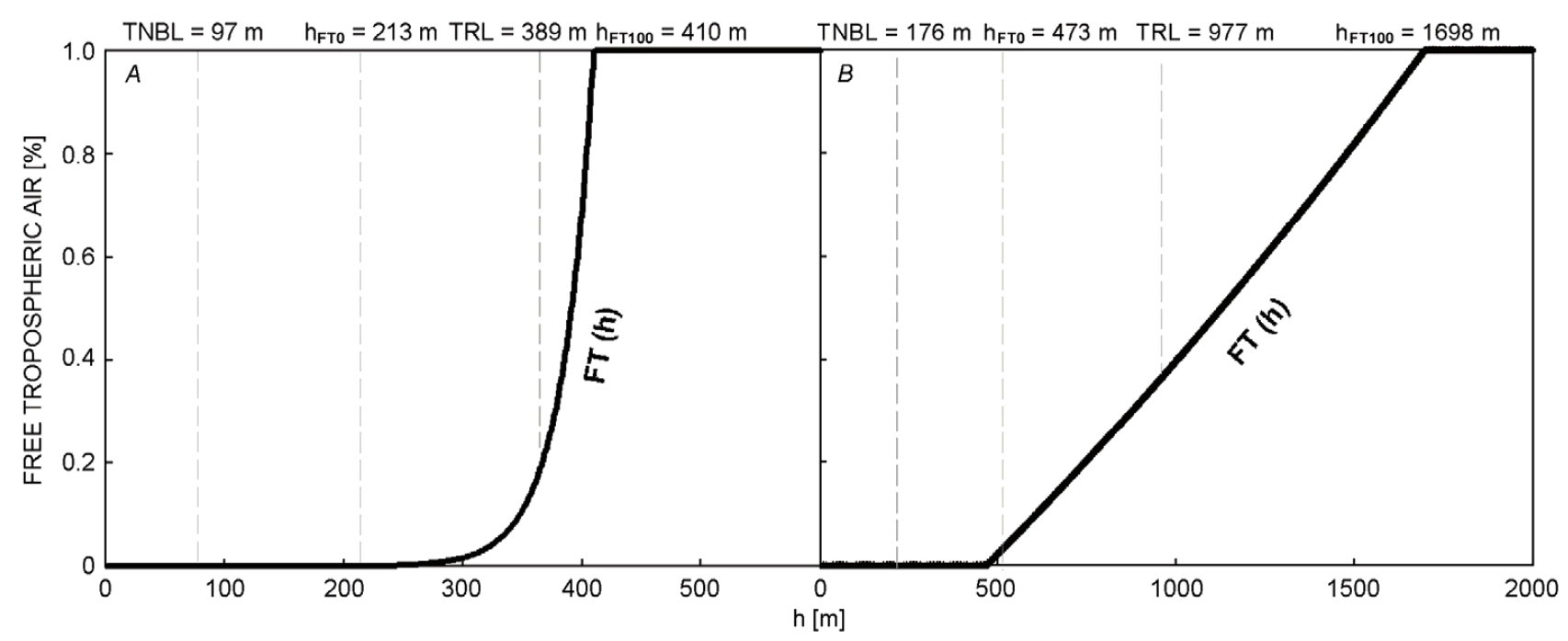

Fig. 1. Examples for the FT(h) function. The function determines the percentage of free tropospheric air in the incorporated air as the function of elevation above ground. $A$ : FT(h) on 12 February, 2002; $\mathrm{k}=7.3 ; B$ : FT(h) on 11 July, 2002.; $\mathrm{k}=0.28 . \mathrm{h}-\mathrm{height}$ of the box.

number of model simulations with randomly varied model parameters but constant input data (Table 1).

To sample the parameter space, 10000 individual parameter sets were constructed randomly with parameter values uniformly distributed in their ranges.

In each simulation step, the likelihood (L) value (degree of fit between simulated and measured data) was calculated, using $\mathrm{CO}_{2}$ mixing ratio data. We have defined the simple L measure as follows:

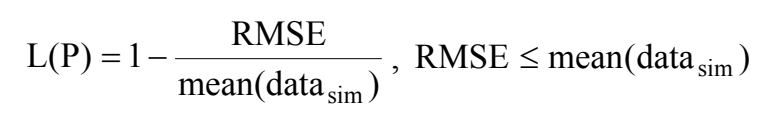

if $\mathrm{RMSE}>$ mean $\left(\right.$ data $\left._{\text {sim }}\right)$ then $\mathrm{L}(\mathrm{P})=0$

$$
\mathrm{RMSE}=\sqrt{\frac{\sum\left(\text { data }_{\mathrm{mes}}-\text { data }_{\mathrm{sim}}\right)^{2}}{\mathrm{n}}}
$$

where RMSE is the root mean square error of the simulation, $\mathrm{P}$ is the given parameter set, data $\mathrm{s}_{\text {sim }}$ is the simulated time series, data mes $_{\text {in }}$ is the measurement data, mean $\left(\right.$ data $\left._{\text {mes }}\right)$ is the average value of the measured data, and $\mathrm{n}$ is the number of simulated and measured data.

The value of $\mathrm{L}$ approaches 0 if the RMSE of the simulation is close to mean $\left(\right.$ data $\left._{\text {mes }}\right)$; and the value of $\mathrm{L}$ tends to 1 if the RMSE tends to 0. If the RMSE is greater than the average value of the measured data, the likelihood value is 0 .The most important step of the

\section{Results}

For the simulation we used NEE, TR, LE, air temperature, VPD and radiation data measured at Hegyhátsál, as well as the daily averaged atmospheric pressure and the 3-hourly ECMWF boundary layer height interpolated calibration is the selection of the a priori range of the model parameters. The values of parameters FT0 and FT100 are allowed to vary from 0 to 1 and the power of the exponential function may change from 1.0 to positive infinity. We have conducted a 1000 -step test calibration, by changing only the value of parameter $\mathrm{k}$ on the $a$ priori interval $[1 ; 1000]$ and studying its effect on $\mathrm{L}$. The results show, that if $\mathrm{k}>10$, the value of the likelihood does not change significantly. Based on Eq. 22 the likelihood function varies between 0 and 1 . Regarding to parameter $\mathrm{k}$ ( $\mathrm{k}$ must be positive), the [0;10] a priori interval was selected.

We performed the calibration of the model using data measured in 2003, because data coverage of $\mathrm{CO}_{2}$ flux measurements was the most complete in that year. After 10000 iteration steps the calculated L function (Eq. 22) was evaluated. The optimal parameter values were determined from the maximum value of the $\mathrm{L}$ function $\left(\mathrm{FT}_{\text {summer }}=0.30, \mathrm{FT}_{\text {winter }}=0.40, \mathrm{FT} 100_{\text {summer }}=0.92\right.$, FT100 ${ }_{\text {winter }}=0.07, \mathrm{k}_{\text {summer }}=0.28, \mathrm{k}_{\text {winter }}=7.3$ ). The model was calibrated using data measured in 2003, and it was validated against data from 2002. As the result of calibration the model explained $30 \%$ of the measured $\delta^{13} \mathrm{C}_{\mathrm{air}}$ variance $\left(R^{2}=0.34\right)$ and the relative error was $3.6 \%$ (before calibration: $R^{2}=0.12$, relative error: $12 \%$ )

Fig. $1 A, B$ illustrate TNBL, TRL, $\mathrm{h}_{\mathrm{FT} 0}, \mathrm{~h}_{\mathrm{FT} 100}$, as well as the shape of the function FT(h) in winter (on 12 February 2002) and in summer (on 11 July 2002).

to hourly resolution. The model results were compared to hourly $\mathrm{CO}_{2}$ mixing ratio and momentary $\delta^{13} \mathrm{C}_{\text {air }}$ data available from flask samples taken once a week. If in a simulation hour the monitoring level $(82 \mathrm{~m})$ was above 


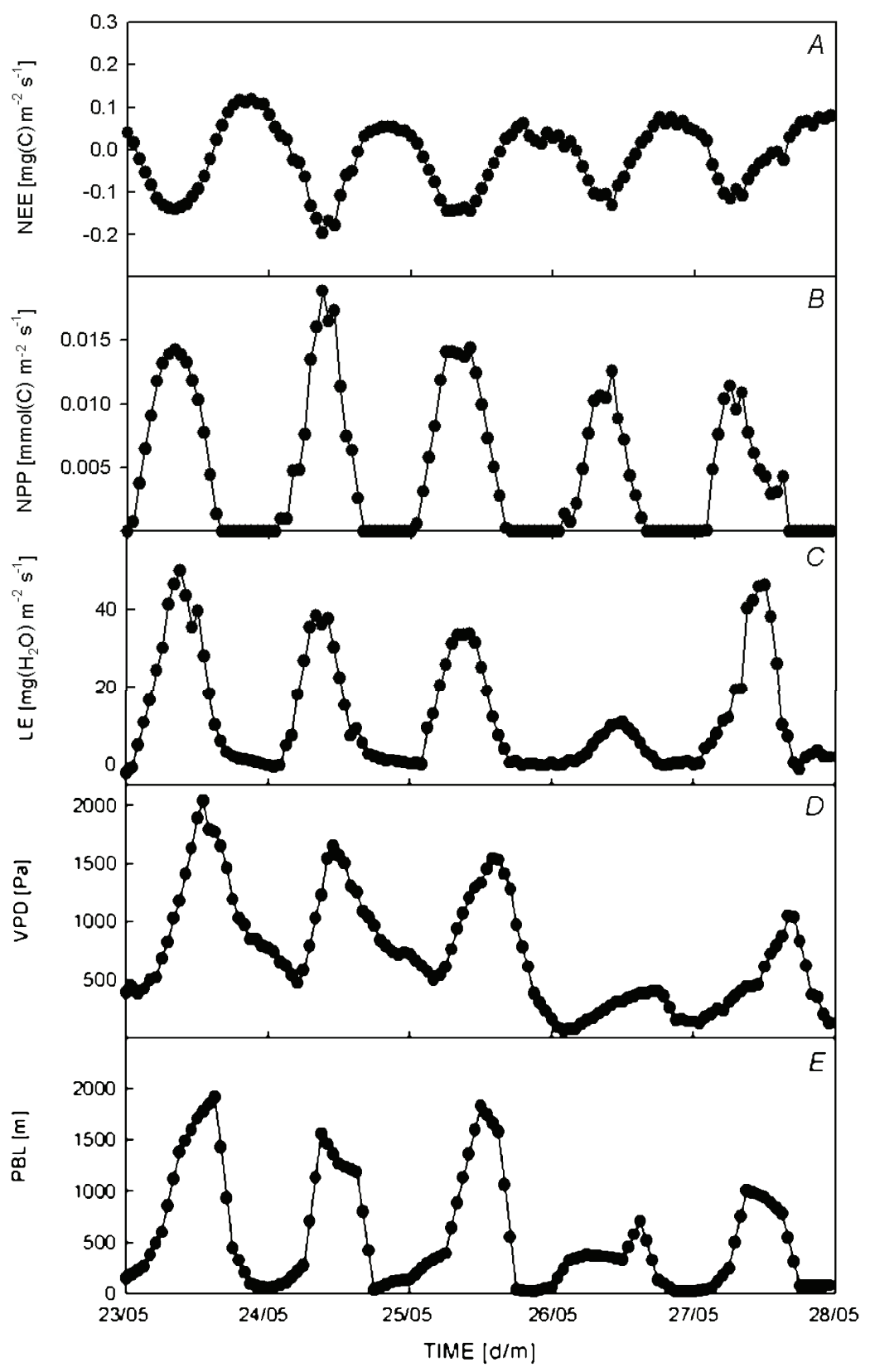

Fig. 2. Diurnal variations in the measured carbon dioxide and water fluxes, vapor pressure deficit and in the height of the boundary layer at Hegyhátsál during 23-27 May (at 00:00 h), 2002. $A$ : net ecosystem exchange (NEE); $B$ : net primary production (NPP); $C$ : latent heat flux (LE); $D$ : vapor pressure deficit (VPD); $E$ : height of the boundary layer (PBL). the height of the boundary layer represented by the box the simulated and measured $\mathrm{CO}_{2}$ mixing ratio data were discarded, because then the monitoring system does not sample the boundary layer for which the simulation is valid. Such a situation was common during calm nights.

The model has a hourly time step. To present the simulated hourly data two periods have been chosen: 23-27 May, 2002 (growing season) and 11-15 February, 2002 (dormant period). Modeled $\mathrm{CO}_{2}$ mixing ratios followed the measurements in each period $(R=0.63$ in the growing season, $R=0.64$ in the dormant period).

Growing season: The model input parameters (carbon and water fluxes, vapor pressure deficit and height of boundary layer) at Hegyhátsál are shown in Fig. 2 for an example period of 23-27 May, 2002. NEE varied between -0.20 and $0.12 \mathrm{mg}(\mathrm{C}) \mathrm{m}^{-2} \mathrm{~s}^{-1}$ (Fig. 2A). NPP had similar courses every day; the maximum value reached $0.02 \mathrm{mmol}(\mathrm{C}) \mathrm{m}^{-2} \mathrm{~s}^{-1}$ (Fig. 2B). Latent heat flux varied between -2.19 and $52.1 \mathrm{mg}\left(\mathrm{H}_{2} \mathrm{O}\right) \mathrm{m}^{-2} \mathrm{~s}^{-1}$ (Fig. 2C) and peaked on the first simulation day. VPD varied between 70 and $2040 \mathrm{~Pa}$ (Fig. 2D) and it was the highest on the first simulation day. The height of the boundary layer peaked at $2000 \mathrm{~m}$ on the first three days, while it was only about 500-700 $\mathrm{m}$ during the other days (Fig. 2E).

The model input and validating parameters are shown in Fig. 3 for the same example period of 23-27 May 2002: measured and simulated diurnal variations in $\mathrm{CO}_{2}$ mixing ratios, modeled difference between ambient and inner-leaf $\mathrm{CO}_{2}$ concentrations $\left(\Delta \mathrm{c}=\mathrm{c}_{\text {air }}-\mathrm{c}_{\text {leaf }}\right)$, simulated 


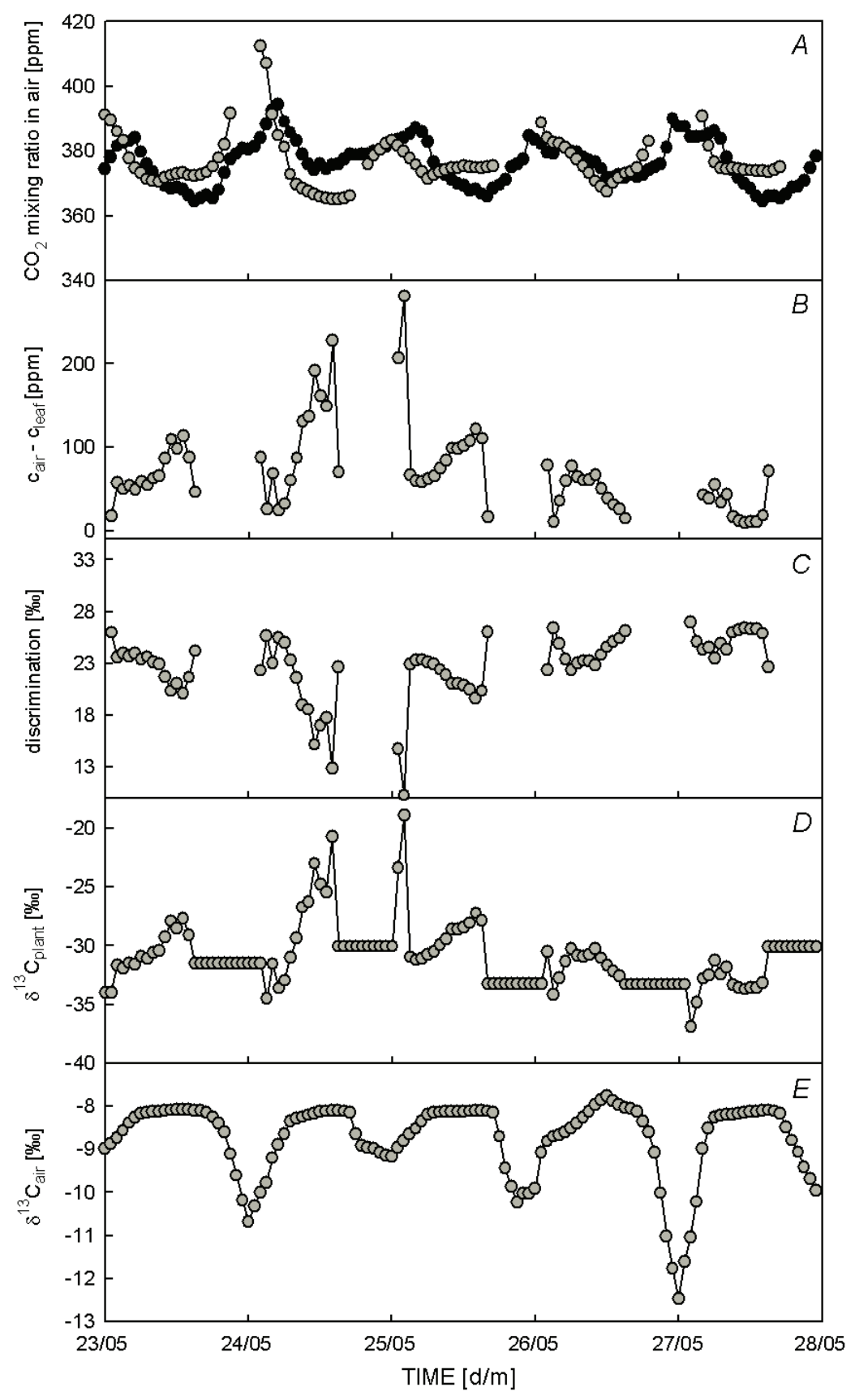

Fig. 3. Diurnal variations in measured and modeled $\mathrm{CO}_{2}$ mixing ratio, in modeled difference between ambient and inner-leaf $\mathrm{CO}_{2}$ concentration, $\delta^{13} \mathrm{C}_{\text {plant }}$ data and $\delta^{13} \mathrm{C}_{\mathrm{air}}$ data during 23-27 May (at 00:00 h), 2002 at Hegyhátsál (the simulated $\mathrm{CO}_{2}$ concentration can not be compared to the measured if the height of PBL is less than the height of the measurement tower; discrimination can not be interpreted and $\Delta \mathrm{c}$ can not be calculated in the simulation hours when NPP is 0 ). $A$ : measured (black dots) and modeled (gray dots) $\mathrm{CO}_{2}$ mixing ratios; $B$ : difference between ambient and inner-leaf $\mathrm{CO}_{2}$ concen-tration $\left(\mathrm{c}_{\text {air }}-\mathrm{c}_{\text {leaf }}\right)$; c) discrimination data $(\Delta) ; \quad D: \quad \delta^{13} \mathrm{C}_{\text {plant }}$ data; $E: \delta^{13} \mathrm{C}_{\text {air }}$ data.). diurnal variations of discrimination $(\Delta)$, and isotope compositions of air and plant material $\left(\delta^{13} \mathrm{C}_{\text {plant }}\right.$ and $\left.\delta^{13} \mathrm{C}_{\text {air }}\right)$.

During daytime the mixing ratio of $\mathrm{CO}_{2}$ decreased, the difference between ambient $\mathrm{CO}_{2}$ concentration and $\mathrm{CO}_{2}$ concentration in the leaf $(\Delta \mathrm{c})$ was greater than $50 \mathrm{ppm}$ (i.e. increased with the $\mathrm{CO}_{2}$ assimilation rate), while during net source periods (from sunset to early morning), the mixing ratio of $\mathrm{CO}_{2}$ increased, the $\Delta \mathrm{c}$ was less than $50 \mathrm{ppm}$ (i.e. decreased with the increasing respiration). Modeled $\mathrm{CO}_{2}$ mixing ratios captured both the diurnal and day-to-day variability of measured $\mathrm{CO}_{2}$ data (Fig. $3 A, B$ ).

Measurement of the discrimination and carbon isotope ratio of plant material $\left(\delta^{13} \mathrm{C}_{\text {plant }}\right)$ requires special equipments and it is time-consuming (Chen et al. 2006). The simulated $\delta^{13} \mathrm{C}_{\text {plant }}$ and discrimination data are in the expected range (e.g. from -35 to $-20 \%$ and from 13 to $30 \%$, respectively) (Jones et al. 1992; Bowling et al. 2008). In Fig. $3 B$ and $3 C$ it can be seen that $\Delta c$ and discrimination took contrary courses (the higher is the $\mathrm{CO}_{2}$ concentration gradient, the smaller is the discrimination as it was expected according to Eq. 18).

Carbon isotope ratio of plant material $\left(\delta^{13} \mathrm{C}_{\text {plant }}\right)$ is determined by discrimination. The smaller the discrimination, the less depleted the plant material in ${ }^{13} \mathrm{C}$, because if the discrimination is small, more ${ }^{13} \mathrm{C}$ is 


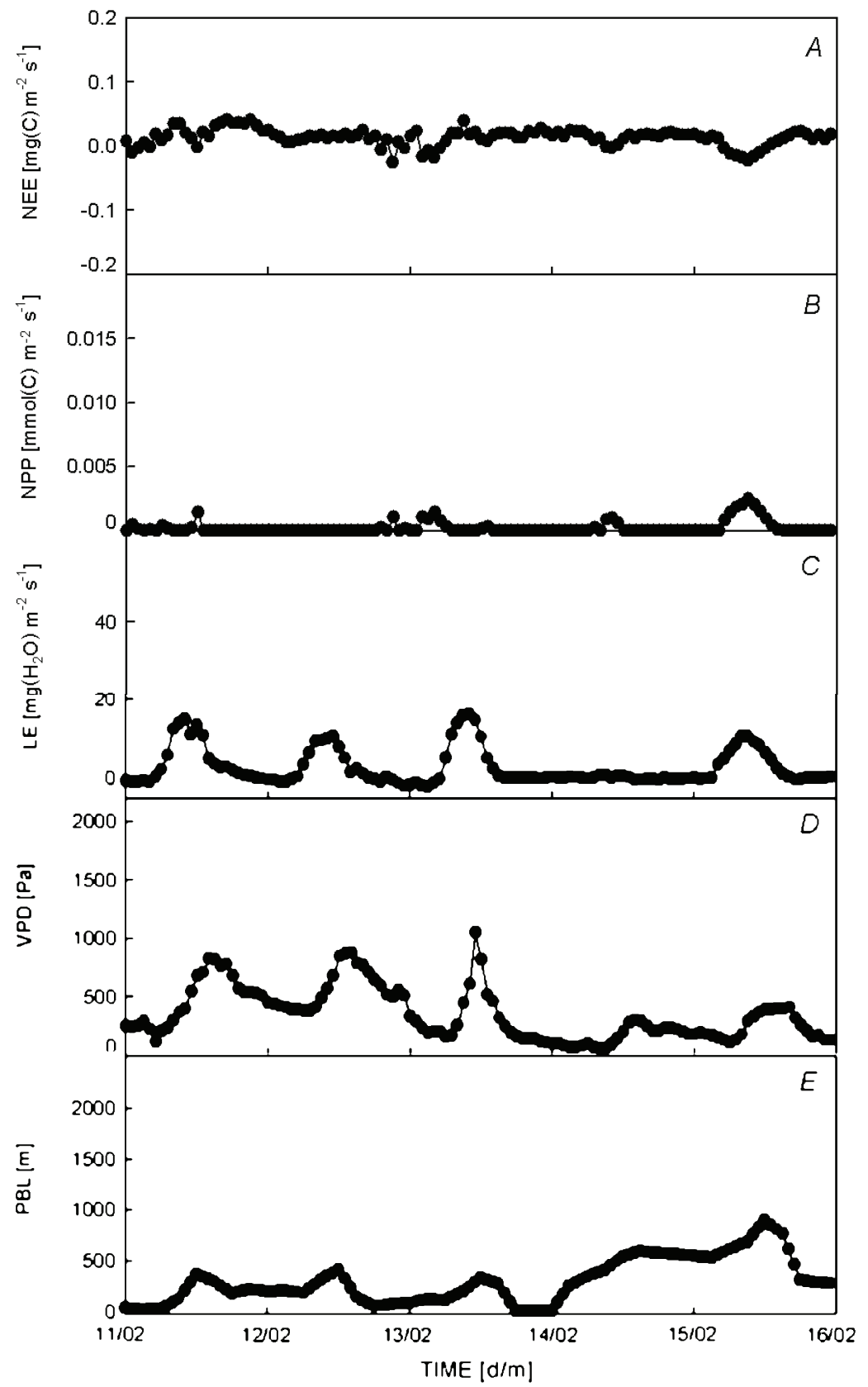

Fig. 4. Same as Fig. 2, but for 11-15 February 2002.

assimilated (Fig. 3D).

Carbon isotope ratio of air $\left(\delta^{13} \mathrm{C}_{\text {air }}\right)$ is partly determined by $\delta^{13} \mathrm{C}_{\text {plant }}$ (Fig. $3 E$ ). If the plant material is depleted in ${ }^{13} \mathrm{C}$, then the released $\mathrm{CO}_{2}$ is also depleted, which causes more depleted $\mathrm{CO}_{2}$ content in the air. Daytime $\mathrm{CO}_{2}$ was enriched in the heavier ${ }^{13} \mathrm{C}$ isotope while during net source periods $\mathrm{CO}_{2}$ was depleted in it (more negative values).

Dormant period: The model input parameters (carbon and water fluxes, VPD, height of PBL) at Hegyhátsál are shown in Fig. 4 for the second example period of 11-15
February, 2002. Net ecosystem exchange had mostly positive values (net carbon release) and varied in a narrow range (Fig. 4A). Consequently, the net primary production (NPP) was 0 in most of the hours. The maximum value and the mean value were smaller than in the growing season by about $87 \%$ and $96 \%$, respectively (Fig. $4 B$ ). LE varied between -2.1 and $16.36 \mathrm{mg}\left(\mathrm{H}_{2} \mathrm{O}\right)$ $\mathrm{m}^{-2} \mathrm{~s}^{-1}$. The maximum value and the mean value of latent heat flux were smaller than in the growing season by about $68 \%$ and $78 \%$, respectively (Fig. $4 C$ ). VPD varied between 60 and $1050 \mathrm{~Pa}$ (Fig. 4D). The height of the boundary layer peaked at $900 \mathrm{~m}$ on the last simulation 


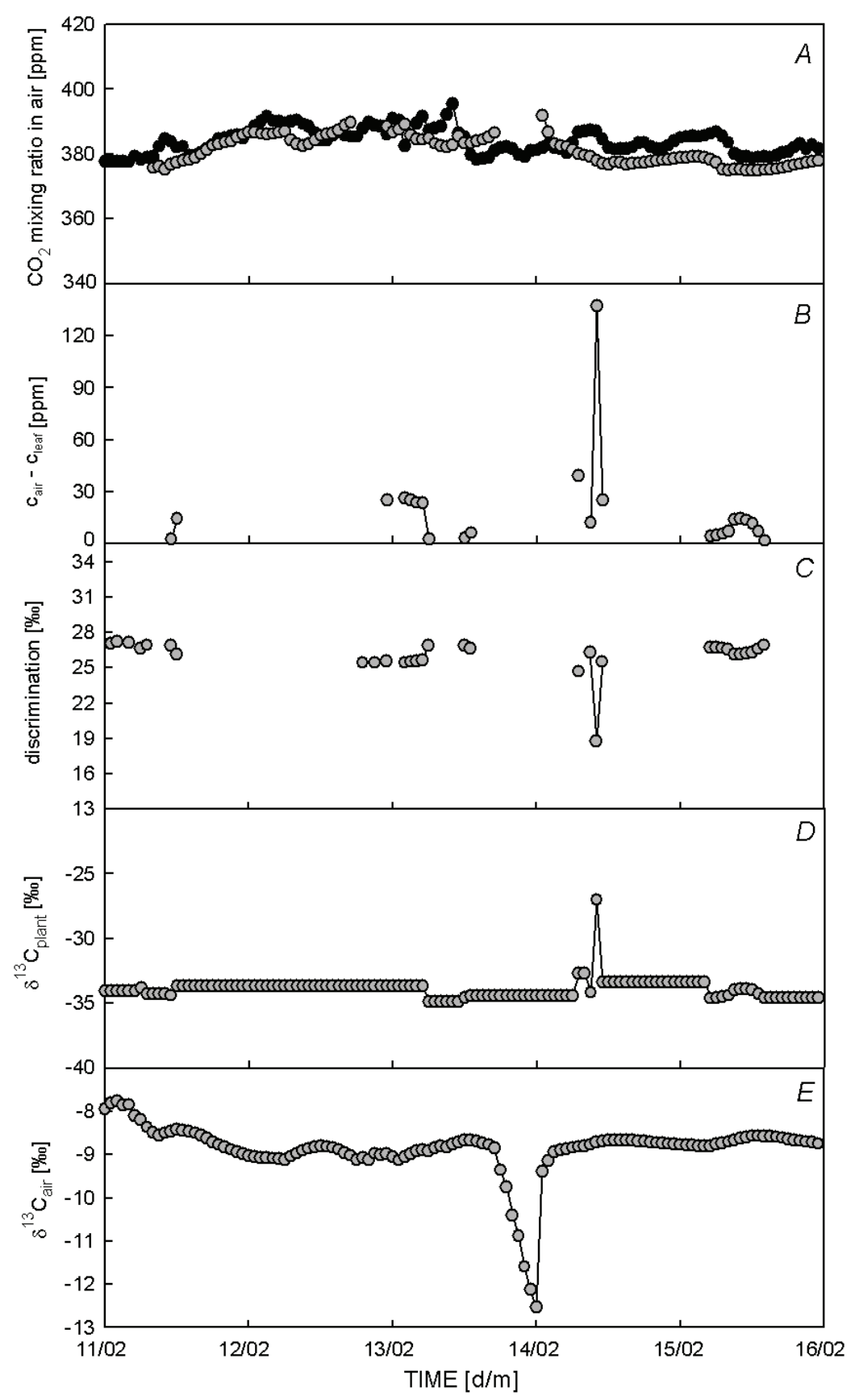

Fig. 5. Same as Fig. 3, but for 11-15 February, 2002.

day, but on the other days at only about $500 \mathrm{~m}$. The mean value of the PBL was smaller by about $50 \%$ than in the growing season (Fig. 4E).

The model input and validating parameters are shown in Fig. 5 for the period of 11-15 February, 2002: measured and simulated diurnal variations in $\mathrm{CO}_{2}$ mixing ratios, modeled difference between ambient and innerleaf $\mathrm{CO}_{2}$ concentrations $(\Delta \mathrm{c})$, discrimination and simulated diurnal variations of isotope composition $\left(\delta^{13} \mathrm{C}_{\text {plant }}\right.$ and $\delta^{13} \mathrm{C}_{\text {air }}$ ). Discrimination can not be interpreted and $\Delta \mathrm{c}$ can not be calculated in the simulation hours when the net primary production (NPP) is 0 .

The mean value of the $\mathrm{CO}_{2}$ mixing ratio was higher than in the growing season by about $3 \%$ (growing season mean value of $\mathrm{CO}_{2}: 365 \mathrm{ppm}$, dormant period: $375 \mathrm{ppm}$ ), the mean value of $\delta^{13} \mathrm{C}_{\text {air }}$ was more negative by about $2 \%$ because of the dominance of respiration process (growing season: $-8.71 \%$, dormant period: $-8.85 \%$ ).

There was one huge peak in the $\Delta c$ course (and therefore in the discrimination and the isotope composition of plant course, too) at $10.00 \mathrm{AM}$ on $14^{\text {th }}$ February (Fig. 5B,C and $D$ ). This is because of the high 

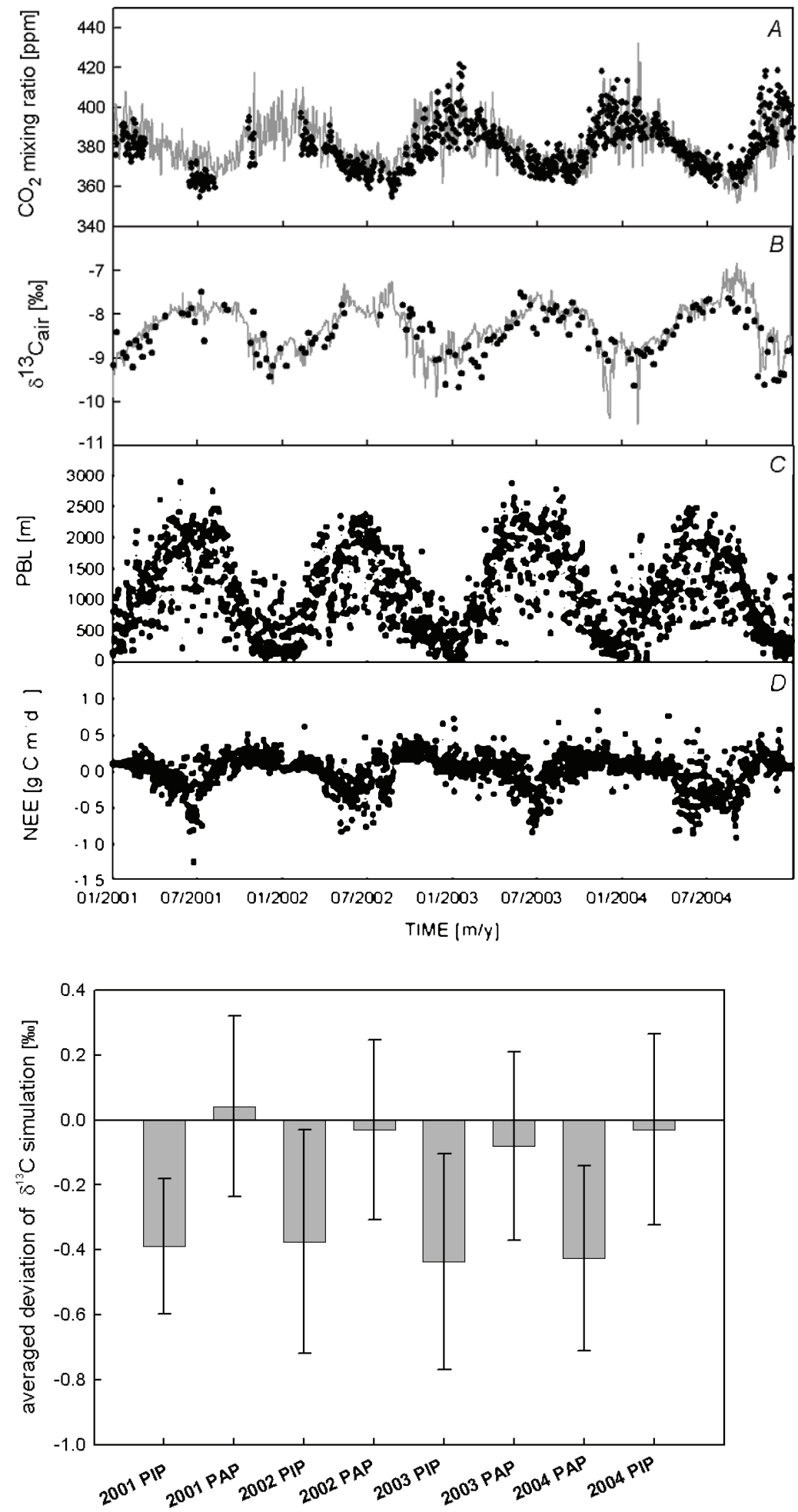

Fig. 6. Annual variations of measured and modeled $\mathrm{CO}_{2}$ mixing ratios and $\delta^{13} \mathrm{C}_{\text {air }}$ data, height of the boundary layer and measured carbon fluxes at Hegyhátsál in 2001-2004. A: measured (black dots) and modeled (gray solid line) $\mathrm{CO}_{2}$ mixing ratios; $B$ : measured (black dots) and modeled (gray solid line) $\delta^{13} \mathrm{C}_{\text {air }}$ data; $C$ : height of the planetary boundary layer; $D$ : net ecosystem exchange (NEE).

Fig. 7. Average difference between the measured and simulated $\delta^{13} \mathrm{C}_{\text {air }}$ data in 20012004 at Hegyhátsál. X-axis shows the photosynthetically inactive periods (PIP, from 15 October to 15 April) and the photosynthetically active periods (PAP, from 16 April to 14 October) are shown for 2001-2004. The error bars mean the standard deviations of the average differences.

NPP $\left(0.003 \mathrm{mmol}(\mathrm{C}) \mathrm{m}^{-2} \mathrm{~s}^{-1}\right)$ and the low latent heat flux $\left(0.45 \mathrm{mg}\left(\mathrm{H}_{2} \mathrm{O}\right) \mathrm{m}^{-2} \mathrm{~s}^{-1}\right)$ in this simulation hour (the ratio of these quantities - which is used to calculate $\Delta \mathrm{c}$ according to Eq. 15 - is higher than in the previous and the next hours by about $70 \%$ ). The carbon isotope ratio of plant material $\left(\delta^{13} \mathrm{C}_{\text {plant }}\right)$ did not change when there was no net carbon assimilation.
In addition to the carbon fluxes, $\mathrm{CO}_{2}$ and $\delta^{13} \mathrm{C}_{\text {air }}$ mixing ratios are influenced by the height of the boundary layer too. There was a peak in $\delta^{13} \mathrm{C}_{\text {air }}$ at midnight on $14^{\text {th }}$ February probably due to the very shallow stable boundary layer (Fig. $5 E$ ). The height of the boundary layer determines also the height (and so the volume) of the model domain (i.e. the box) and 


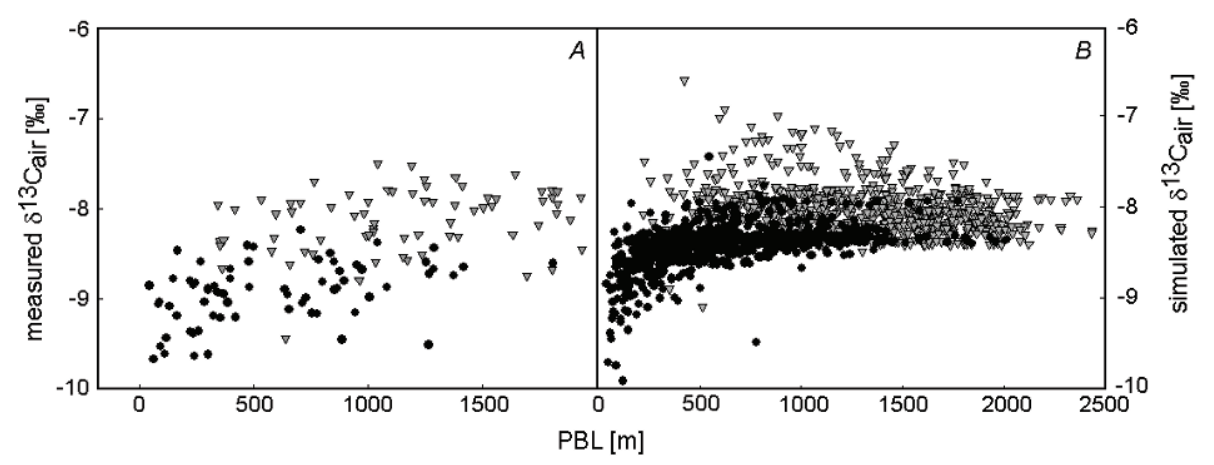

Fig. 8. Relation between measured $(A)$ and modeled $(B) \delta^{13} \mathrm{C}_{\text {air }}$ data and boundary layer height for 2001-2004 at Hegyhátsál. Black dots represent the data from the photosynthetically inactive periods (from 15 October to 15 April), while gray triangles represent data from photosynthetically active periods (from 16 April to 14 October).

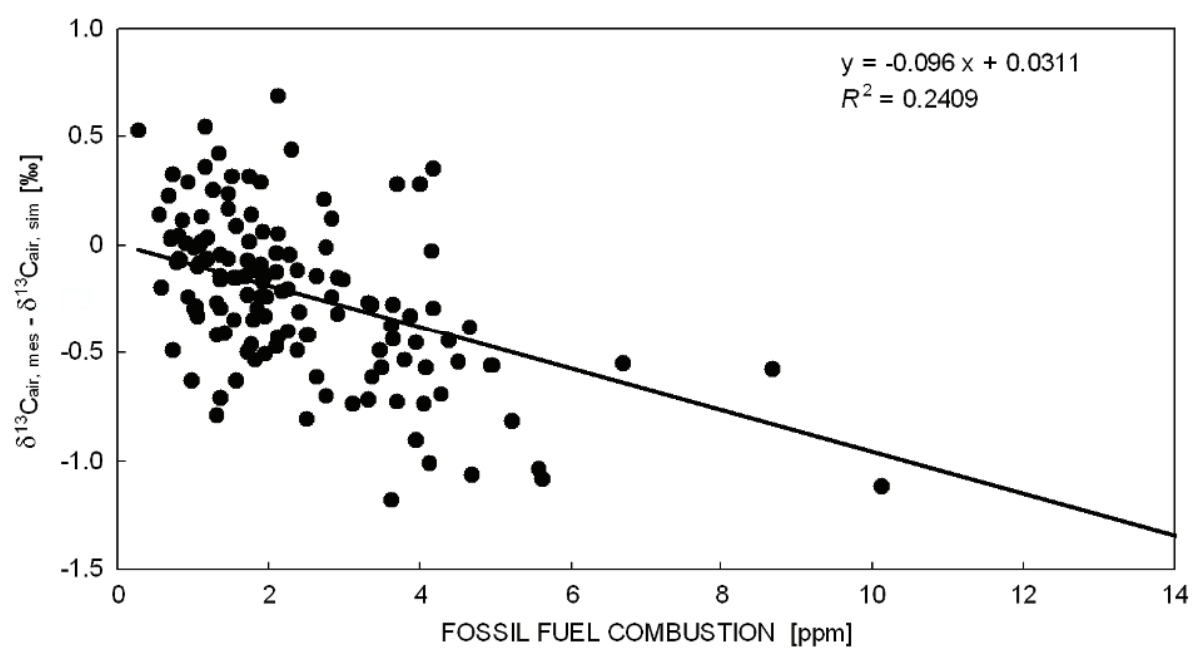

Fig. 9. Relation between fossil fuel (contribution COMET transport model) and error of the $\delta^{13} \mathrm{C}_{\mathrm{air}}$ simulation (difference between measured and simulated data by $13 C$ FLUX model)

consequently the mixing ratios are affected not only by plant/ecosystem functioning. The smaller the volume of the box (i.e. the shorter the box is), the stronger the vegetation will influence the $\mathrm{CO}_{2}$ and $\delta^{13} \mathrm{C}_{\text {air }}$ mixing ratios (Fig. 8).

Seasonal variation of the atmospheric data: The model was run for the period 2001-2004. For a comparison of the simulated $\delta^{13} \mathrm{C}_{\text {air }}$ values with the measurements, the early afternoon mean values of simulated $\delta^{13} \mathrm{C}_{\text {air }}$ were also calculated for those days when air samples for ${ }^{13} \mathrm{CO}_{2}$ analyses were taken. Based on the early afternoon mean values, seasonal dynamics of $\mathrm{CO}_{2}$ (Fig. $6 A$ ) and $\delta^{13} \mathrm{C}_{\text {air }}$ mixing ratios (Fig. 6B) were examined. The model captured both the magnitude of the variation and the seasonal dynamics $(R=0.63$, mean absolute error: $8.32 \mathrm{ppm}$ regarding to the simulation of $\mathrm{CO}_{2}$ mixing ratio, $R=0.72$, mean absolute error: $0.32 \%$ regarding to the simulation of $\delta^{13} \mathrm{C}_{\text {air }}$ mixing ratio).

We examined the correlation between the input and the output model data. We found that the two most important factors (with the highest $R^{2}$ values between input data and simulated $\mathrm{CO}_{2}$ and $\delta^{13} \mathrm{C}_{\text {air }}$ mixing ratios) are the height of the planetary boundary layer and NEE $\left(R_{\mathrm{CBL}, \mathrm{CO} 2}^{2}=0.33, R_{\mathrm{CBL}, 813 \mathrm{Cair}}^{2}=0.35, R_{\mathrm{NEE}, \mathrm{CO} 2}^{2}=0.23\right.$, $R_{\mathrm{NEE}}^{2} \delta 13$ Cair $=0.31$ ). In the growing seasons NEE is negative, the vegetation is a net $\mathrm{CO}_{2}$ sink therefore the atmospheric $\mathrm{CO}_{2}$ mixing ratio is lower. The uptake process discriminates against the heavier isotope in this period; therefore air is more enriched in ${ }^{13} \mathrm{C}$ (less negative values). On the other hand, PBL values are much higher (because of the more intensive turbulence) during the growing season, therefore the above influence of the vegetation is weakened; so the $\mathrm{CO}_{2}$ and the $\delta^{13} \mathrm{C}_{\text {air }}$ mixing ratios tend to get closer to the free atmospheric $\mathrm{CO}_{2}$ and the $\delta^{13} \mathrm{C}_{\text {air }}$ mixing ratios

The deviations between the measured and simulated $\delta^{13} \mathrm{C}_{\text {air }}$ mixing ratios $\left(\delta^{13} \mathrm{C}_{\text {air, mes }}-\delta^{13} \mathrm{C}_{\text {air, sim }}\right)$ were examined (Fig. 7). The differences were negative during the photosynthetically inactive periods (15 October 15 April) and positive but much smaller during the photosynthetically active periods (16 April - 14 October). The simulation overestimated the measured values during photosynthetically inactive periods in each year. In 
photosynthetically active periods (16 April - 14 October) the above mentioned deviations were equally distributed among the years considering their signs, and they were smaller than in the photosynthetically inactive periods by an order of magnitude.

We postulate that the systematic deviation during photosynthetically inactive periods is linked to the higher fossil fuel use and shallower boundary layer during winter. Since the $\delta^{13} \mathrm{C}$ mixing ratio in fossil fuel (considering natural gas, which is widely used for heating in Hungary) is $-44 \%$, the atmospheric $\mathrm{CO}_{2}$ may become more depleted in ${ }^{13} \mathrm{C}$ (Meijer et al. 1996). This effect might have been further enhanced by lower PBL height.

The above reasoning is also partially supported by data showing the profound effect of the boundary layer height on the measured $\delta^{13} \mathrm{C}_{\text {air }}$ mixing ratios (Fig. 8). During photosynthetically active periods higher boundary layer and higher $\delta^{13} \mathrm{C}_{\text {air }}$ values were co-occurring and it

\section{Discussion}

We introduced a simple model simulating the atmospheric stable carbon isotope ratio and variation of ${ }^{13} \mathrm{C}$ content in plant material using biosphere-atmosphere $\mathrm{CO}_{2}$ flux and meteorological data. The physiologically based approach was successfully applied to calculate discrimination $(\Delta)$ and from measured eddy data (assimilation and transpiration) and air $\mathrm{CO}_{2}$-concentration data. In this way, representation of the discrimination process became more reliable as opposed to other less realistic solutions as taking a constant value of $\Delta$, for example. More importantly, modelling of ${ }^{13} \mathrm{C}$ of air $\mathrm{CO}_{2}$ became also more reliable and the model can serve as an independent tool for calculation of biogenic ${ }^{13} \mathrm{C}$ fluxes (Hegyhátsál is a good candidate for biogenic fluxes) and therefore may be used as a constraint in future investigations regarding fossil fuel $\mathrm{CO}_{2}$ contributions. The model proved to be an appropriate tool to simulate $\delta^{13} \mathrm{C}_{\text {air }}$ variation where eddy flux data were available. Correlation between the measured and simulated $\delta^{13} \mathrm{C}_{\text {air }}$ was 0.72 with a relative error of $3.2 \%$ regarding the validation years (20012004). The corresponding values for atmospheric $\mathrm{CO}_{2}$ mixing ratio were 0.63 and $2.18 \%$. The correlation between the measured and the simulated values is statistically significant at $P<0.01$ probability level. Observed deviations between the measured and simulated $\delta^{13} \mathrm{C}_{\text {air }}$ values were systematically negative in winters, while deviations were random in sign and smaller by an order of magnitude during periods when the vegetation was photosynthetically active. This difference is suggested to be influenced by anthropogenic emission of $\mathrm{CO}_{2}$ strongly depleted in ${ }^{13} \mathrm{C}$ due to fossil fuel based winter heating and also by the lower boundary layer heights during winter periods.

In order to estimate the contribution of fossil fuel $\mathrm{CO}_{2}$ to the concentration at the receptor station Hegyhátsál we was the contrary during photosynthetically inactive periods. The correlations $(R)$ between simulated $\delta^{13} \mathrm{C}_{\text {air }}$ mixing ratios data and the height of the boundary layer were 0.5 and 0.44 for the photosynthetically active and inactive periods, respectively. The relation between these variables is changing with the height of the boundary layer: if the height is below $500 \mathrm{~m}$ the correlation is higher $(R=0.58$ regarding to measured data, $R=0.5$ regarding to simulated data), while higher boundary layers result in lower correlation $(R=0.35$ regarding to measured data, $R=0.12$ regarding to simulated data).

$\delta^{13} \mathrm{C}_{\mathrm{air}}$ mixing ratios are affected both by biogenic and anthropogenic sources. At Hegyhátsál the biogenic fluxes probably dominate this response due to the distant location of the site from anthropogenic pollution sources. Anthropogenic effects may still influence more the measured signal during the winter heating period by high fossil fuel (natural gas) $\mathrm{CO}_{2}$ emission.

used modeled values from the COMET Lagrangian transport model (Vermeulen et al. 2006; Pieterse et al. 2008). In this model a PBL and reservoir layer concentration value are calculated in a method quite similar to the box model deployed in this paper, but in the COMET model the column moves and follows a trajectory path that is calculated from analyzed wind field data from the operational ECMWF weather model. Emissions along the trajectory path are based on the EDGAR V32FT2000 emission database (Olivier et al. 2001), the annual average emissions are scaled to vary hourly by using monthly, weekday and 3-hourly scaling factors per source category, as provided by the EDGAR team. The COMET model results for fossil fuel contributions compared for surface stations very well with results from other transport models in a recent comparison in the CarboEurope-IP Integration component. By combining background concentrations with emissions from fossil fuels with emissions and uptake from the biosphere and from sea surfaces along each trajectory in the COMET model, up to $70 \%$ of the observed variability in the $\mathrm{CO}_{2}$ concentration at the station Hegyhátsál can be explained (Pieterse et al. 2008). As expected the fossil fuel contributions to the $\mathrm{CO}_{2}$ concentration are high in winter time due to higher emissions and lower PBL heights.

The simulated contribution to atmospheric $\mathrm{CO}_{2}$ concentration by fossil fuel combustion modeled by the COMET transport model significantly (at $P<0.01$ probability level), although weakly, correlates to the difference between the measured and simulated $\delta^{13} \mathrm{C}_{\text {air }}$ values, and this relationship is negative further supporting

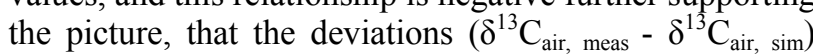
may well be caused by anthropogenic contribution due to gas combustion during winter (Fig. 9). 


\section{References}

Baldocchi, D. D., Falge, E., Gu, L.H., Olson, R., Hollinger, D., Running, S., Anthoni, P., Bernhofer, C., Davis, K., Fuentes, J., Goldstein, A., Katul, G., Law, B., Lee, X., Malhi, Y., Meyers, T., Munger, J. W., Oechel, W., Pilegaard, K., Schmid, H.P., Valentini, R., Verma, S., Vesala, T., Wilson, K., Wofsy, S.: FLUXNET: A new tool to study the temporal and spatial variability of ecosystem-scale carbon dioxide, water vapor and energy flux densities. - Bull. Am. Meteorol. Soc. 82: 2415-2434, 2001.

Bowling, D.R., Pataki, D.E., Randerson J.T.: Carbon isotopes in terrestrial ecosystem pools and $\mathrm{CO}_{2}$ fluxes. - New Phytol. 178: $24-40,2008$

Chen, B.Z., Chen, J.M., Tans, P.P., Huang, L.: Simulating dynamics of-C-13 of $\mathrm{CO}_{2}$ in the planetary boundary layer over a boreal forest region: covariation between surface fluxes and atmospheric mixing. - Tellus Series B-Chem. Phys. Meteorol. 58: 537-549, 2006.

Farquhar, G.D., von Caemmerer, S., Berry J.A.: A biochemicalmodel of photosynthetic $\mathrm{CO}_{2}$ assimilation in leaves of $\mathrm{C}_{3}$ species. - Planta 149: 78-90, 1980.

Farquhar, G.D., Oleary, M.H., Berry, J.A.: On the Relationship between carbon isotope discrimination and the inter-cellular carbon dioxide concentration in leaves. - Austr. J. Plant Physiol. 9: 121-137, 1982.

Farquhar, G.D., Ehleringer, J.R., Hubick, K.T.: Carbon isotope discrimination and photosynthesis. - Annu. Rev. Plant Physiol. 40: 503-537, 1989.

GLOBALVIEW- $\mathrm{CO}_{2} .:$ Cooperative Atmospheric Data Integration Project - Carbon Dioxide. - CD-ROM, NOAA ESRL. Boulder, Colorado (Colorado [Also available on Internet via anonymous FTP to ftp.cmdl.noaa.gov, Path: ccg/co2/GLOBALVIEW]), 2007.

GLOBALVIEW- $\mathrm{CO}_{2} \mathrm{C} 13 .:$ Cooperative Atmospheric Data Integration Project - 13C of Carbon Dioxide. - CD-ROM, NOAA ESRL. Boulder, Colorado ([Also available on Internet via anonymous FTP to ftp.cmdl.noaa.gov, Path: ccg/co2c13/GLOBALVIEW]), 2007.

Harnos, N., Tuba, Z., Szente, K.: Modelling net photosynthetic rate of winter wheat in elevated air $\mathrm{CO}_{2}$ concentracions. Photosynthetica. 40: 293-300, 2002.

Haszpra, L., Barcza, Z., Bakwin, P.S., Berger, B.W., Davis, K.J., Weidinger, T.: Measuring system for the long-term monitoring of biosphere/atmosphere exchange of carbon dioxide. - JGR-Atmospheres 106: 3057-3069, 2001.

Haszpra, L., Barcza, Z., Davis, K.J., Tarczay, K.: Long-term tall tower carbon dioxide flux monitoring over an area of mixed vegetation. - Agri. Forest Meteorol. 132: 58-77, 2005.

Hemming, D., Yakir, D., Ambus, P., Aurela, M., Besson, C.,
Black, K., Buchmann, N., Burlett, R., Cescatti, A., Clement, R., Gross, P., Granier, A., Grunwald, T., Havrankova, K., Janous, D., Janssens, I.A., Knohl, A., Ostner, B.K., Kowalski, A., Laurila, T., Mata, C., Marcolla, B., Matteucci, G., Moncrieff, J., Moors, E.J., Osborne, B., Pereira, J.S., Pihlatie, M., Pilegaard, K., Ponti, F., Rosova, Z., Rossi, F., Scartazza, A., Vesala, T.: Pan-European delta $\mathrm{C}-13$ values of air and organic matter from forest ecosystems. - Global Change Biol. 11: 1065-1093, 2005.

Jones, H.G.: Plants and microclimates. - In: Jones, H.G. (ed.): Plants and Microclimates. Pp.192-200. Cambridge Univ. Press, Cambridge 1992.

Lai, C.T., Ehleringer, J.R., Tans, P., Wofsy, S.C., Urbanski, S.P., Hollinger, D.Y.: Estimating photosynthetic C-13 discrimination in terrestrial $\mathrm{CO}_{2}$ exchange from canopy to regional scales. - Global Biogeochem. Cycles. 18: GB1041, 2004.

Meijer, H.A.J., Smid, H.M., Perez, E., Keizer, M.G.: Isotopic Characterisation of Anthropogenic $\mathrm{CO}_{2}$ Emissions Using Isotopic and Radiocarbon Analysis. - Phys. Chem. Earth 21: 483-487, 1996.

Mosegaard, K., Tarantola, A.: Monte Carlo sampling of solutions to inverse problems. - JGR-Solid Earth 100: 1243112447, 1995.

Olivier, J.G.J., Berdowski, J.J.M.: Global emissions sources and sinks. - In: Berdowski, J., Guicherit, R., Heij, B.J. (ed.): Climate System. Pp. 33-78. A.A. Balkema Publishers/Swets \& Zeitlinger Publishers, Lisse 2001.

Pieterse, G., Vermeulen, A.T., Baker, I.T., Denning, A.S.: Lagrangian transport modelling for $\mathrm{CO}_{2}$ using two different biosphere models. - Atmos. Chem. Phys. Discuss 8: 41174154, 2008

Schulze, E.D.: Biological control of the terrestrial carbon sink. Biogeosciences. 3: 147-166, 2006.

Stull, R.B. (ed.): An Introduction to Boundary Layer Meteorology. Kluwer Academic Publishers, Dordrecht 1988.

Suits, N.S., Denning, A.S., Berry, J.A., Still, C.J., Kaduk, J., Miller, J.B., Baker, I.T.: Simulation of carbon isotope discrimination of the terrestrial biosphere. - Global Biogeochem. Cycles 19: GB1017, 2005.

Van Oijen, M., Rougier, J., Smith, R.: Bayesian calibration of process-based forest models: bridging the gap between models and data. - Tree Physiology 25: 915-927, 2005.

Vermeulen, A.T., Pieterse, G., Hensen, A., van den Bulk, W.C.M., Erisman, J.W.: COMET: a Lagrangian transport model for greenhouse gas emission estimation - forward model technique and performance for methane. - Atmos. Chem. Phys. Discuss. 6: 8727-8779, 2006. 